\title{
Instructional Media Development for Teaching Japanese Language
}

\author{
Dian Bayu Firmansyah ${ }^{1 *}$, Riska Sri Rahmawati² , Andini Qodriya Tanzil ${ }^{3}$ \\ ${ }^{1}$ Universitas Jenderal Soedirman \\ 2,3 Universitas Komputer Indonesia
}

\section{A R T I C L E IN F O}

Article history:

Received 19

February 2018

Received in revised

form

6 March 2018

Accepted 12 April

2018

Available online 24

May 2018

\section{Keywords:}

Multimedia Learning;

Teaching Materials;

Japanese Learning;

Teachers

\begin{abstract}
A B S T R A C T
This research aims to develop multimedia teaching materials for teaching Japanese language at the senior high school. Using Adobe Flash CS5 software, this interactive media was technology based and provided some features found in the source book, such as vocabularies or sentence patterns introduction, etc. In addition this media also equipped by Japanese words pronounciation practice using Online Japanese Accent Dictionary (OJAD). This research was conducted with pre-experimental method, survey questionnaire and a short interview. Research subjects were teachers and students of senior high schools majoring Japanese language in Indonesia. Survey questionnaire result showed that this media was high rated as an attractive media and user-friendly media based on the contents and features provided on it. Further, it was found that this media was very useful not only for teachers as a teaching materials, but also for learners who are eager to learn Japanese independently.
\end{abstract}

\section{Introduction}

Second language learning is one of the critical capabilities to be mastered to face the global competition, which requires individuals to increase their competence in the field of information, science and technology. So mastering one of the international languages that exist in this world is a must for a person who wants to be able to communicate and interact within multiple communities in this global society.

Japanese language is one of the foreign languages studied by students at senior high school level in Indonesia. In some schools, Japanese language is studied by students ranging from class X to class XII as a primary subject or even as the elective subject of interest to students. There are also some schools that introduce Japanese language in Japanese clubs as extracurricular activities.

Recently, digital technology has become a main part of human life. The rise of digital technology also gives a huge impact for the learning environment itself, which can help teachers to teach and presenting the materials more interesting and easy to understand (Sumbawat \& Munoto, 2015).

In most of the schools who are providing Japanese language in Indonesia, the teaching methods used by the teachers is still relies on conventional ways that used only textbook as the main source book for teaching Japanese language in the classrooms. Though students in these days are currently a generation who have grown up with technology and they have never known a world without technology (Maryunita, 2017; SEG Research, 2008). Therefore, it is necessary for teachers to improve their teaching skills by applying digital technology into their teaching tools, to ensure the development of students learning process is in the right way with the expected goals. 
Using multimedia in the teaching and learning environment enables students to become critical thinker, problem-solver, more apt to seek information and more motivated in their learning process (Gulzar, 2014 : 69). According to Zhang (Sumbawat \& Munoto, 2015), with more interactive and richer media available, a learner who prefers an interactive learning style has more flexibility to meet individual needs. Based on that, we assume that application of multimedia-based teaching media is the most appropriate choice for teachers to attract students interest and assist students in understanding the Japanese language materials taught in the classroom.

The problems that often occur is the lack of knowledge of teachers in the process of developing teaching materials based on digital technology, resulting in many teachers who rely on conventional methods in teaching. The discrepancies between methods or media used by teachers and student learning styles can give a bad effect on students, so students tend to find it difficult to accept lessons and even make students lazy to learn (Setianingrum, 2017). Compare to English language, Japanese is more difficult to be mastered by students according to its vocabularies and the Japanese characters (Kanji) used. Therefore, teachers' ability in developing a teaching materials that suits students' needs and learning styles is highly needed.

To solve the problems mentioned above, some teachers have suggested several media to help and improve their ability in teaching Japanese language in the classroom, including power point based media image picture (Setianingrum, 2017), internet site (Yanto \& Djunaidi, 2011), google Japanese input (Maryunita, 2017), etc. Although these media are attractive and enhance students motivation, apparently several limitations was found. Specifically, the suggested media was not user friendly for students that wants to learn independently outside the classrooms. Because the suggested media mentioned above was designated only when students learned in a classrooms and cannot be done without the teachers help.

According to Mayer's cognitive theory of multimedia learning (2005), it also states that learning is an active process of filtering, selecting, organizing and integrating information. So the learning media used have to suits to learners needs in terms of selecting a materials that they want to learn.

With user friendly (interactive) multimedia, it can allow learners to be part of the learning process, experiencing control over the content and manipulate the acquisition process, so the students can go beyond the limits and become the core of teaching and learning process (Neo's \& Yap, 2008 : 659; Gulzar $2014: 69$ ). The advent of multimedia technologies can change the way educators teach and students learn, because the communication of the information can be done in a more effective manner (Gulzar, 2014).

Therefore, the development of interactive media to enhance the way of teaching and learning Japanese language is much more needed than before. The major purpose of this study were: (1) to determine teachers-students responses on the instructional media; (2) to seek a possibility for using an ICT based instructional media in Japanese language teaching-learning and (3) to offer the implications of the present study for teachers in Indonesian high schools. The present study addressed the research questions: (1) how does the teachers-students responses toward instructional media?; (2) Is there any possibility for using an ICT based instructional media in the real learning environment?

Multimedia learning is a cognitive theory which has been popularized by the work of Richard E. Mayer and others (Sorden, 2012). Mayer (2009) defines multimedia instructions as a presentation of materials using both words and pictures, with intention of promoting learning. Meanwhile, Neo, and Neo (2001) give more specific explanation and define multimedia as a combination of various types of media such as text, images, sound and video into an integrated multisensor application, to deliver messages and information to audiences.

Heinrich states that the main purpose of media is to facilitate communication and learning (Heinrich, 1996 in Nawangnugraeni \& Subiyanto, 2015). Multimedia learning occurs when people build mental representations from words and pictures (Mayer, 2005). This kind of learning offers a significant opportunity to reach the greatest number of students and most effectively support students with different learning styles (SEG Research, 2008). Therefore, to enhance the effectivity of learning process, teachers should be able to design and implement a several instructional models to attract students interest and assist students in understanding materials taught in the classroom.

In several studies, it is stated that application of multimedia-based teaching media is the most appropriate choice to enhance learning motivation and improve learning outcomes (Sumbawat \& Munoto, 2015 ; Nawangnugraeni \& Subiyanto, 2015). Multimedia technologies would make students become an active participants in their own learning process and students will be quicker to understand the material because of the basic principles of multimedia that convey information through two main channels of Audio and Visual (Neo \& Neo's, 2001 ; Mayer, 2009) 
The results of Neo \& Neo's study (2001) shows that integrating multimedia into the teaching and learning process enables students to excercise their creative and critical thinking skills in solving their design and development problems, work collaboratively to gain team-based experience and help them to acquire good problem solving skills.

\section{Method}

This research was conducted through pre-experimental method (Thyer, 2012). To collect data for the expected usage of multimedia for teaching purpose, a simple structured survey questionnaire was prepared. This method employed five points Lickert scale, that research subject have to respond to each statements of the survey questionnaire by selecting: 1 (Never or almost never true of me/strongly disagree), 2 (Usually not true of me/disagree), 3 (somewhat true of me/neutral), 4 (Usually true of me/agree) and 5 (always or almost always true of me/strongly agree). Some short interview also was conducted as a complimentary research data.

Questionnaire and interview was conducted to confirm the impact of the media implementation in real Japanese language class and to gain some valuable information about the media advantages or disadvantages for further instructional media development.

All data collected by questionnaires was input into SPSS 16.0 and the percentage of each statement was interpreted based on Table 1.

Table 1. Questionnaire Score

\begin{tabular}{ll}
\hline Interval of Percentage & Category \\
\hline $0 \%-20 \%$ & Very bad \\
$21 \%-40 \%$ & Bad \\
$41 \%-60 \%$ & Enough \\
$61 \%-80 \%$ & Good \\
$81 \%-100 \%$ & Very Good \\
\hline
\end{tabular}

(Adopted from Sugiyono, 2007)

A total of 22 Japanese language teachers from various cities in Indonesia and 8 students from various Indonesian senior high schools who were majoring Japanese language, has participated in this study. The samples were selected by random sampling method, on the basis of convenience and availability. Samples consisted of 20 female and 2 male for teachers, 4 female and 4 male for students.

Instructional design applied in this present research refers to the ADDIE models which are acronym for Analysis, Design, Development, Implementation and Evaluation of learning materials and activities (Branch, 2009 ; McGriff, 2000). This learner-centered instructional design consists of the following stages:

1. Analysis Stage

This stage was aimed to determining the teachers and students needs, analysis of learning objectives, analysis of materials and completeness of software produced.

2. Design Stage

Consists of preparation of teaching media software development, such as making the storyboard, activity diagram design and materials establishment needed in the software.

The software used in this study was Adobe Flash Professional CS 6 and Adobe Photoshop 6. Further, Online Japanese Accent Dictionary (OJAD) was applied to downloaded the audio source used in the software.

3. Development Stage

Based on the storyboard which have been made, the software will be next developed as to create a prototype of teaching software. Media validation and assesment by expert also conducted in this stage. The assessment of teaching software includes the assessment of text, graphics, sound, animation and learning materials inside.

4. Implementation Stage

The implementation of interactive teaching media software development is adjusted to the teaching model applied. The teachers and students are able to use the software to confirmed the performance of the teaching media software. This stage was trial stage aimed to find out the teachers and students responses of the media feasibility.

5. Evaluation Stage 
In this stage, the evaluation was conducted to find out the advantage as well as the disadvantage of the teaching media developed. Software improvement and refinement need to be carried out in order to be perfect and ready to use in actual classes. Evaluation stages was divided into two kinds of evaluation which are formative evaluation conducted in every development phase and summative evaluation conducted in the end of the whole process.

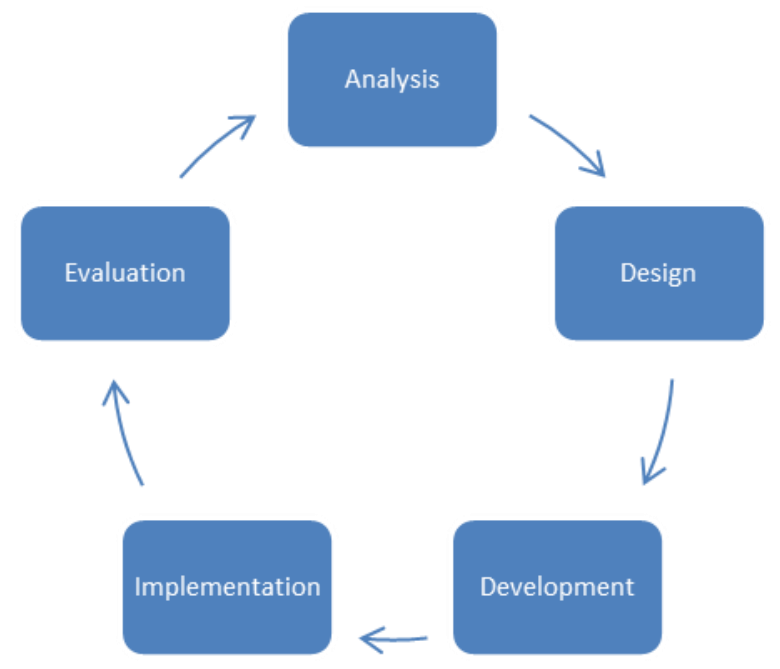

(adopted from Branch, 2009)

\section{Discussion}

Figure. 1 ADDIE Model

This media was high technology multimedia based, displayed with a Flash Player and can be accessed by students at any time. This instructional media software also a user-friendly media, so it can be used easily by students by running the command buttons. Variations of color, motion animations, effects and attractive icons also added to improve the performance of instructional media software.

The instructional media software design shown in Figureure. 2, contains Opening menu, Syllabus, Lesson, Test, About and Setting menu button as a main function of the media. The Syllabus menu contains of information about subjects to learn.
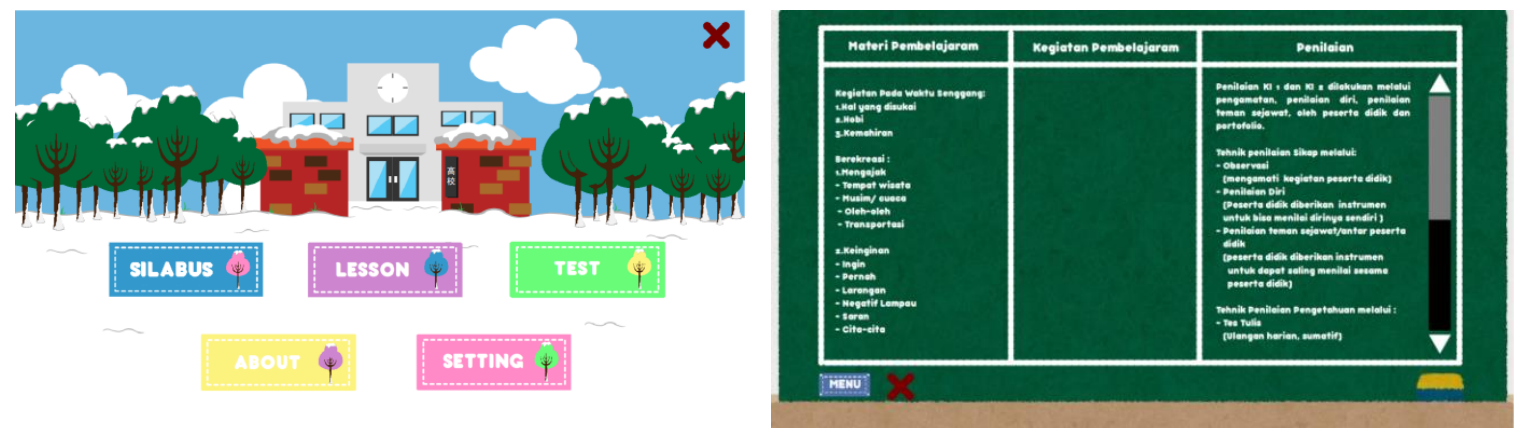

Figure. 2 Opening \& Syllabus Menu Display

The Lesson menu contains of the Speaking (Kaiwa), Vocabularies, Japanese Characters, Grammar and practice buttons were arranged based on the chapter in the source book (see Figure. 3) 

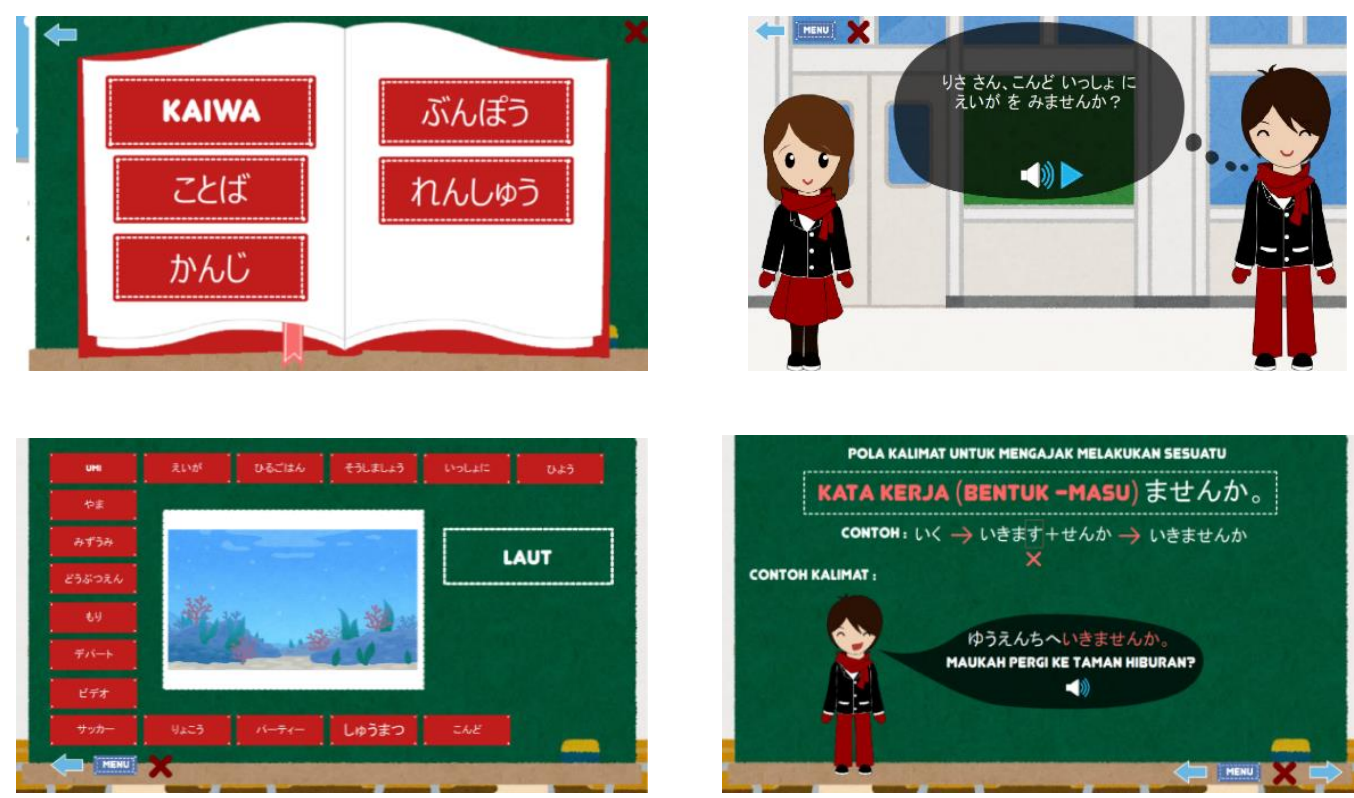

In the Quiz menu, it contains two types of quiz: multiple choice and sentences arrange quiz as shown in Figure. 4 as follows. The appearance of score after the quiz is also presented, in which this is used for self-evaluating the learners skill after learring the subjects.
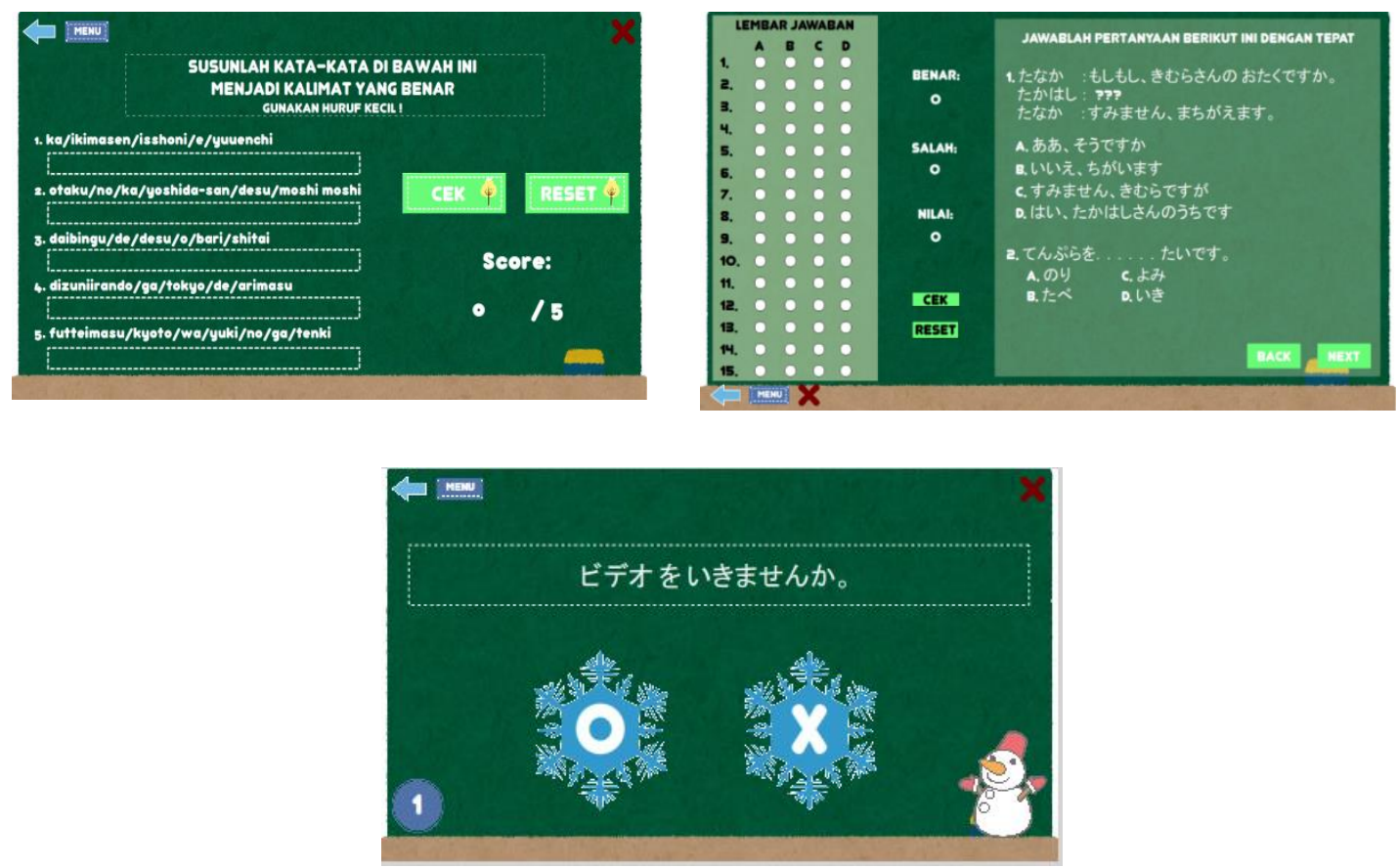

Figure. 4 Appearance of Quiz Menu Contents

The validation of instructional media consists of media graphics, audio/language and content, conducted by two experts. The obtained average value from the two experts were 3,82 which is resulted as an interesting criteria (See Table 2). This result also showed that this media is suitable as a teaching material. 
Table 2. Result of Instructional Media Validation

\begin{tabular}{|c|c|c|c|c|}
\hline \multirow[t]{2}{*}{ No } & \multicolumn{2}{|r|}{ Validation Subject } & \multicolumn{2}{|c|}{ Validator } \\
\hline & & & 1 & 2 \\
\hline \multirow[t]{9}{*}{$\mathbf{A}$} & \multicolumn{2}{|c|}{ Graphic } & & \\
\hline & 1 & Media design & 4 & 3 \\
\hline & 2 & Suitability of Picture Size & 4 & 3 \\
\hline & 3 & Animations or Text & 5 & 3 \\
\hline & 4 & Type of Font & 5 & 4 \\
\hline & 5 & Illustration Display & 4 & 4 \\
\hline & 6 & Picture Sharpness & 4 & 4 \\
\hline & 7 & Color Selections & 4 & 3 \\
\hline & 8 & Navigation Buttons & 5 & 3 \\
\hline \multirow[t]{5}{*}{ B } & \multicolumn{2}{|c|}{ Audio/Language } & & \\
\hline & 1 & Clarity of Background Music & 5 & 3 \\
\hline & 2 & Clarity of Buttons Sound & 4 & 3 \\
\hline & 3 & Japanese Spelling & 4 & 3 \\
\hline & 4 & Commands/Instruction & 4 & 3 \\
\hline \multirow[t]{3}{*}{$\mathbf{C}$} & \multicolumn{2}{|c|}{ Content } & & \\
\hline & 1 & Suitability of Media Content & 5 & 3 \\
\hline & 2 & User Guide & 5 & 3 \\
\hline Total & & & 62 & 45 \\
\hline Average & & & 4.42 & 3.21 \\
\hline
\end{tabular}

The questionnaire for teachers (See Table 3) consists of 14 statement related to the contents and the appearance/function of the instructional media. The questionnaire result showed that the percentage of teachers response in each statements was categorized as "Very Good" (more than 81 \%). It indicates that this media categorized as easy to use and suitable for teaching Japanese language in the actual classrooms.

Table 3. Teachers Means and Percentage $(n=22)$

\begin{tabular}{clcc}
\hline No & Statements & Mean Score & \% \\
\hline 1 & Vocabulary contents were relevant to the source book & 4.36 & 95.5 \\
2 & Grammar contents were relevant to the source book & 4.41 & 100 \\
3 & Examples were relevant to the source book & 4.36 & 100 \\
4 & Practice menu questions were suitable & 3.68 & 82 \\
5 & Difficulty level of the questions were suitable & 3.95 & 91 \\
6 & Illustrations were well organized & 4.18 & 91 \\
7 & Contents presentation was easy to understand & 4.23 & 100 \\
8 & Text and font size presented very clear and easy to read & 4.27 & 100 \\
9 & Type of used font & 4.27 & 100 \\
10 & Navigation buttons was well organized and easy to use & 4.32 & 100 \\
11 & Sound effect was clear and appropriate & 3.86 & 86 \\
12 & Native speaker pronounciation feature presented very clear & 4.09 & 91 \\
13 & Instructional media overall appearances was good & 4.23 & 100 \\
14 & This instructional media was suitable for teaching Japanese in & 4.23 & 100 \\
& actual class & & \\
\hline
\end{tabular}

Survey questionnaire result showed that the media scored very high in the survey (means score around 4.0) on the Lickert scale. Specifically, there was several items from the questionnaire that received a high score (means score above 4.0), such as "vocabulary contents were relevant to the source book" $(\mathrm{m}=4.36, \mathrm{p}=95.5)$, "grammar contents were relevant to the source book" $(\mathrm{m}=4.41, \mathrm{p}=100)$, "examples were relevant to the source book" ( $\mathrm{m}=4.36, \mathrm{p}=100)$, "illustrations were well organized" $(\mathrm{m}=4.18, \mathrm{p}=91)$, "contents presentations was easy to understand" $(\mathrm{m}=4.23, \mathrm{p}=100)$, "Text and font size presented very clear and easy to read" ( $\mathrm{m}=4.27, \mathrm{p}=100)$, "Type of used font" $(\mathrm{m}=4.27, \mathrm{p}=100)$, "Navigation buttons was 
well organized and easy to use" ( $\mathrm{m}=4.32, \mathrm{p}=100)$, "Native speaker pronounciation feature presented very clear" ( $\mathrm{m}=4.09, \mathrm{p}=91)$, "Instructional media overall appearances was good" $(\mathrm{m}=4.23, \mathrm{p}=100)$ and "This instructional media was suitable for teaching" $(m=4.23, p=100)$.

From these responses, it indicates that the features provide in the media allowed them to create a student centered learning environment and they can teach Japanese more fun than before. It also helped teachers to increase students learning motivation.

Table 4. Teachers comments on the use of interactive media

\section{Teaching Japanese Language using interactive media}

a. Provide a good learning environment and more enjoyable for both of the teachers and students

b. The display of the media helped me to teach the contents better than the traditional way

c. It helped the students to review the materials given in the class and prepare for the next meeting

$\mathrm{d}$. The contents is organized well and various features found in the media is very suitable for a new way

of teaching

Japanese

e. I don't have to spent a lot of time just to doing a preparation before the class

Students Responses Towards The Interactive Media

Students survey questionnaire consist of 16 statements related to the contents and the appearance/function of the instructional media (See Table 5). Based on questionnaire result, the percentage of students response in each statements was also categorized as "Very Good" (more than 81 $\%$ ). It indicates that this media categorized as an attractive and user friendly. The content and features provided also are useful for students to learn independently outside the classrooms.

Table 5. Students Means and Percentage $(n=8)$

\begin{tabular}{clcc}
\hline No & \multicolumn{1}{c}{ Statements } & Mean Score & \% \\
\hline 1 & Vocabulary contents is relevant to the source book & 4.62 & 100 \\
2 & Grammar contents is relevant to the source book & 4.62 & 100 \\
3 & Examples are relevant to the source book & 4.62 & 100 \\
4 & Practice menu questions are relevant to the source book & 3.62 & 75 \\
5 & Difficulty level of the questions are relevant to the source & 4.88 & 100 \\
& book & 4.38 & 100 \\
6 & Illustration is well organized & 4.62 & 100 \\
7 & Contents presentation is easy to understand & 3,87 & 87,5 \\
8 & The design is attractive and innovative & 4.00 & 100 \\
9 & Text and font size presented very clear and easy to read & 4.25 & 87,5 \\
10 & Type of used font & 3.75 & 75 \\
11 & Navigation buttons is well organized and easy to use & 3.50 & 75 \\
12 & Sound effect is clear and appropriate & 4.25 & 100 \\
13 & Native speaker pronounciation feature presented very clear & 4.88 & 100 \\
14 & Language program used in the media is easy to understand & 100 \\
15 & Instructional media overall appearances is good and & 4.88 & 100 \\
& increase learning motivation & & \\
16 & This instructional media is suitable for teaching Japanese in & 4.75 & \\
& actual class & & \\
\hline
\end{tabular}

Table 5 showed that there was a positive responses from the students on the using of instructional media for their Japanese language learning process. Several items from the questionnaires that scored high score were: "vocabulary contents were relevant to the source book" $(\mathrm{m}=4.62, \mathrm{p}=100)$, "grammar contents were relevant to the source book" ( $\mathrm{m}=4.62, \mathrm{p}=100)$, "examples were relevant to the source book" $(m=4.62, p=100)$, "Difficulty level of the questions are relevant to the source book" $(m=4.88, p=100)$ ", "Illustrations were well organized" $(\mathrm{m}=4.38, \mathrm{p}=100)$, "Contents presentations was easy to understand" $(\mathrm{m}=4.62, \mathrm{p}=100)$, "Text and font size presented very clear and easy to read" $(\mathrm{m}=4.00, \mathrm{p}=100)$, "Type of used font" $(m=4.25, p=87.5)$, "Native speaker pronounciation feature presented very clear" $(m=4.25$, $\mathrm{p}=100)$, "Language program used in the media is easy to understand" $(\mathrm{m}=4.88, \mathrm{p}=100)$, "Instructional media overall appearances is good and increase learning motivation" $(\mathrm{m}=4.88, \mathrm{p}=100)$ and "This 
instructional media is suitable for teaching Japanese in actual class" $(m=4.75, p=100)$. Students interview result was shown in Table 6.

Table 6. Students comments on the use of interactive media

\section{Learning Japanese Language using interactive media}

a. It easy to use and made learning process more effective

b. The contents really helpful for those who wants learn Japanese independently

c. The one click translations button and native speaker conversation features guide me to knows

Japanese better

d. The media really suits to my learning style

From the survey questionnaires and short-interviews result, it is clear that the the teachers and students responses towards the instructional media were positives. It also indicates that this had a great impact on students way of learning Japanese language. In general, both of teachers and students confirmed that they were enjoyed to learn Japanese using the media and satisfied with all the features embed in the media.

The first part that must be discussed in this present study is the main reason for the development of Japanese language teaching-learning software media. Japanese language is well known as one of the difficult language to learn. Therefore, teachers have to give an extra effort in order to guide the students learn Japanese in more enjoyable learning situation and the subjects can be done in more effective manner. Although many studies have been discovered a various of kind of Japanese teaching styles, the learning process will easily occur if we found good carrier device that is popular (Haristiani \& Firmansyah, 2017).

Computer-related technology has proven itself to be generally useful in the field of education, in particular, as teaching and learning tools (Karim \& Shukur, 2016). The combination of visual and auditory media were effective in enhancing students understanding of the subject matter and motivated them to learn more about it (Mayer, 2001; Clark \& Mayer 2003). Multimedia can offer layers of beneficial resources, provide large amounts of information to learners (Shank, 2008). This is the essential factors that made the teaching-learning process through the multimedia software was better than the traditional ways.

This way of learning also changing the learning behaviour from teacher centric learning to student centered learning process, whereby teachers act as the facilitator of learning, guiding and supporting learners in the process of constructing knowlegde (Neo \& Neo, 2001). In the other hand, learners become active and they can set their own pace in learning, which led them to enjoy their learning process and this is in line with Neo, Neo \& Yap (2008), Shank (2008), Mayer (2005), SEG Research (2008) positions on the effectiveness of multimedia in learning.

The second part in this study is how to get users understand and learn faster about the language. Research finding indicates that multimedia elements such as images, animation and audio were very useful for students in term to enhance their understanding of the subject. Presented information using visual and auditory channel can made working memory to handle more information and increase the amount of information that the brain can process (SEG Research, 2008 \& Sweller, 2005).

Applying ADDIE model, the media was effectively designed to properly support the students needs. They expressed strongly that the features such as the subject curriculum, practice menu and quiz menu, brought a lot of benefits that allowed students to determine their pace of learning, kept them actively engaged in their learning outside the class. Then, since the objective of this media is for Indonesian learners, the software must be supported with their mother language. Supporting media with their mother language will give benefits for making faster in understanding foreign language (Butzkamm, 2003). In addition, user-friendly navigation system embbed in the media, provided learners a media that they can use it with no limitations to time and place, particularly the teachers existence in their independent learning process.

\section{Conclusions and Reccomendation}

In this study, we developed multimedia based teaching materials. Attractive contents and features provide in the media is believed to serve as an effective way for teachers to teaching Japanese language and to improve students learning motivation in the classroom. Finally, survey questionnaire and short 
interview result showed positive responses from the teachers and students, confirming that the media was innovative, attractive, user friendly and very useful for real learning environment. Interesting suggestions obtained from teachers and students also become very useful information for future media development.

Since this research investigates only the teachers-students impressions on the use of the media, future studies is highly recommended to observe what kind of result will be obtained if this media is used in actual Japanese language class as an experimental tools.

\section{References}

Branch, R. M. 2009. Instructional Design: The ADDIE Approach. Newyork : Springer Science Business Media.

Gulzar, Z. 2014. Educational System of J\&K in the light of Evolutionary Multimedia Technology: A Case Study. International Journal of Advance Research in Computer Science and Management Studies. Volume 2, Issue 4, April 2014, pp. 66-75.

Karim, N.A and Shukur, Z. 2016. Proposed Features on An Online Examination Interface Design and Its Optimal Values. Computers in Human Behaviour, 64, 414-442.

Maryunita, R. 2017. Pemanfaatan Aplikasi Google Japanese Input dalam Meningkatkan Minat dan Kemampuan Membaca Teks Bahasa Jepang. Japanedu Journal. Vol. 2, No. 1, June 2017, pp. 20-28.

Mayer, R. E. 2005. Introduction to Multimedia Learning in R. E. Mayer (Ed). The Cambridge Handbook of Multimedia Learning. Newyork: Cambridge University Press.

Mayer, R. E. 2009. Multimedia Learning: Second Edition. Newyork: Cambridge University Press.

McGriff, S. J. 2000. Instructional System design: Using ADDIE Model. Available online at: https://www.lib.purdue.edu/sites/default/files/directory/butler38/ADDIE.pdf [July, 3rd 2017 Accesed]

Nawangnugraeni, D. A \&Subiyanto. 2015. A New Variant of Android Educational Game as the Facility Introduction of Number for Early Childhood. Proceedings of the International Conference on Innovation in Engineering and Vocational Education, November 14, 2015. Bandung : Atlantis Press.

Neo, M \& Neo, K. 2001. Innovative Teaching: Using Multimedia in a Problem Based Learning Environment. Educational Technology \& Society 4(4) 2001.

Neo, M, Neo, K \& Yap, W. 2008. Student's Perceptions of Interactive Multimedia Mediated Web-Based Learning: A Malaysian Perspective. Proceedings Ascilite Melbourne 2008. http://www.ascilite.org.au/conferences/melbourne08/procs/neo.pdf Haristiani, N \& Firmansyah, D. B. 2017. Android Application For Enhancing Japanese JLPT N5 Kanji Ability. Journal of Engineering Science and Technology Special Issue on AASEC 2016, October (2017), pp. 106-114. School of Engineering, Taylor`s University.

SEG Research. 2008. Understanding Multimedia Learning: Integrating Multimedia in the K-12 Classroom. Available online at: https://www.brainpop.com/new common images/files/76/76426 BrainPOP White Paper20090426.pdf [July, 3rd 2017 Accesed]

Setianingrum, M. 2017. Penggunaan Variasi Media Ajar Terhadap 3 Gaya Belajar Siswa Dalam Pembelajaran Bahasa Jepang. Japanedu Journal. Vol. 2, No. 1, June 2017, pp. 1-8.

Shank, P. 2008. The Value of Multimedia in Learning. The E-Learning Guild Online Forum 501, pp. 1-13.

Sugiyono. 2007. Metode Penelitian Bisnis. Bandung: Alfabeta. 
Sorden, S. D. 2012. The Cognitive Theory of Multimedia Learning. Available online at: http://sorden.com/portfolio/sorden draft multimedia2012.pdf [July 27th 2017 Accessed]

Sumbawat, M.S \& Munoto. 2015. The Development of Instructional Video to Illustrate Teaching in a Real Learning Environment. Proceedings of the International Conference on Innovation in Engineering and Vocational Education, November 14, 2015. Bandung : Atlantis Press.

Thyer, B. A. 2012. Quasi-Experimental Research Design. Oxford Scholarship Online: May 2012, DOI:10.1093/acprof:oso/9780195387384.003.0002.

Yanto, A.N \& Djunaidi, A. 2011. Meningkatkan Keterampilan Membaca Bahasa Jepang Melalui Pemanfaatan Media Internet Situs JPLANG. TEKNOSASTIK Journal. Volume 9, Issue 2, 2011, pp. 47-52. 